\title{
Legal regulation of tax control in the Eurasian Economic Union: environmental implications
}

\author{
I. Ignatovskaya, N. Grinchinko, V. Zubkova \\ Altai State University, 61 Lenina St, Barnaul, 656049, Russian Federation \\ *Corresponding author E-mail: \\ Received: 20.10.2020. Accepted 30.11.2020
}

\begin{abstract}
Economic integration of states within the Eurasian Economic Union implies the creation of not only international agreements regulating economic relations, but also harmonization and unification of national environmental legislation. This research is devoted to the issues of legal regulation of forms of environmental tax control in the national legislation of the EAEC member states: Russian Federation, Republic of Belarus, Republic of Kazakhstan, Kyrgyz Republic, and Republic of Armenia. The identified regularities in the legal regulation of forms of tax control may be the basis for the development of unified approaches to tax control in the territory of the Eurasian Economic Union member states.
\end{abstract}

Keywords: tax control, forms of tax control, tax audits, tax monitoring, harmonization of tax legislation, model Tax Code.

\section{Introduction}

The Treaty on the establishment of the Eurasian Economic Union entered into force on January 01, 2015 (Treaty, 2014 ). The first five-year anniversary allows to analyze what has already been done for the development of this organization and what should be done in the near future.

It should be noted that with the establishment of the Eurasian Economic Union (hereinafter - EEU) has begun full-scale integration in the economic sphere, one of the most important conditions of which is the convergence of the tax systems of the EEU member states, contributing to the creation and development of a single domestic market. At present, the main strategic objectives in the field of EEU tax policy are:

- promoting competitiveness in global markets;

- ensuring tax neutrality and preventing disproportions;

- defining the directions, as well as the forms and procedures for harmonizing legislation on taxes that affect mutual trade;

- improvement of tax control over the activity of subjects of economic relations in mutual trade (A Review, 2019).

It is the implementation of the fourth strategic task in the field of tax policy that interests us the most in this study, since the development of common approaches in the implementation of tax control measures makes the control itself more effective.

\section{Materials and methods}

The object of the research in this article is a set of social relations formed in connection with the implementation of tax control. The subject of the study is the legal norms that establish and regulate the forms and procedures for carrying out control measures by the tax authorities of the EAEC Member States.

The basis for the study was the provisions of the national tax legislation of the EEEC Member States.

To conduct the research, a complex of complementary research methods was used: systematic, comparative legal, formal and legal, and analogy. Their application allowed to consider the object of the study in a holistic and comprehensive manner.

\section{Results and discussion}

At present, in the EAEC member states tax control is regulated by national tax codes.

In the Russian Federation, tax control is regulated by Part One of the Russian Tax Code (The Tax Code, 2019a). Article 82 of the Tax Code of the Russian Federation recognizes under tax control the activities of the authorized bodies to control compliance with legislation on taxes and duties in the manner prescribed by this Code. Tax control is exercised by officials of tax authorities within their competence through 
- tax audits,

- obtaining explanations from taxpayers, tax agents and fee payers, insurance premium payers,

- verification of accounting and reporting data,

- inspection of premises and territories used for generating income (profit),

- as well as in other forms provided by this Code. The analysis of the current provisions of the Tax Code of the Russian Federation allows highlighting such a new form of tax control as tax monitoring.

At the same time, an analysis of the provisions of Chapter 14 "Tax Control" of the Tax Code allows us to draw a clear conclusion that such forms of tax control as obtaining explanations from taxpayers and other persons, verification of accounting and reporting data, inspection of premises and territories used for the extraction of income (profit) can not be carried out by officials of tax authorities other than as part of tax audits. This circumstance leads to the conclusion that despite the relatively large number of forms of tax control known under Russian tax law; only two types of tax audits and tax monitoring are used in practice. Pursuant to Article 87 of the Russian TC, tax audits are divided into desk audits and on-site audits.

Unfortunately, the current Russian tax legislation does not define the place of such a very important tax control measure as taxpayer registration, but only regulates the procedure for its implementation. In our opinion, we should take advantage of the positive experience of Belarusian tax law in this area and define taxpayer accounting as a form of tax control.

According to Article 71 of the General Part of the Tax Code of the Republic of Belarus, "tax control is a system of measures to control the implementation of tax legislation carried out by tax officials within the limits of their authority by: recording taxpayers (other obliged persons); carrying out audits" (The Tax Code, 2018). Thus, it may be concluded that Belarusian tax legislation establishes two forms of tax control: registration of fiscal obliged persons and tax audits. In turn, as in the Russian Federation, tax audits are divided into desk audits and field audits.

Kazakhstani tax legislation considers tax control to be quite extensive, meaning "state control exercised by tax authorities over the execution of tax legislation of the Republic of Kazakhstan and other legislation of the Republic of Kazakhstan, control over which is vested in the tax authorities" (The Tax Code, 2019b). In accordance with Art. 69 of the Tax Code of the Republic of Kazakhstan, tax control in this state is carried out in the form of tax audits and other forms of state control, which in turn are divided into registration of taxpayers with the tax authorities; reception of tax forms; desk audit; tax monitoring; tax inspection; control over the accounting of ethyl alcohol in organizations engaged in the production of ethyl alcohol.

Tax control is also exercised in the Kyrgyz Republic through the functions of tax authorities. Article 93 of the Tax Code of the Kyrgyz Republic establishes the following forms of tax control: tax registration and registration of the taxpayer; accounting of tax revenues to the budget; tax audit; raid tax control; establishment of a tax post (The Tax Code, 2019c).

The regulation of tax control in the Republic of Armenia is very detailed. The Tax Code of the Republic of Armenia provides for Part 3, which is called "Part of tax administration" (The Tax Code, 2017). The tax legislation of the Republic of Armenia, as well as of the Russian Federation, does not consider registration of taxpayers as a form of tax control, but fixes it as a measure of tax administration. Tax control is defined in Article 328 of the Tax Code of the Republic of Armenia as "state control over the fulfillment of the requirements of legal acts, which give the tax authority to control, - the totality of actions of the tax authority (its officials) provided for by the Code within the limits of the authority given to the tax authority". Tax control in the Republic of Armenia is exercised in three forms: 1) tax audits; 2) tax audits; 3) other actions established by the Code and the laws of the Republic of Armenia within the framework of tax administration (Article 333 of the RA Tax Code). Tax audits, in turn, are divided into complex and thematic audits. The tax legislation of the Republic of Armenia does not divide tax audits into desk audits and field audits, as do other EAEC member-states.

The analysis of the tax legislation of the EAEC member states allows us to conclude that if there is a unity of approaches to the definition of the concept of "tax control", the states determine differently the forms and procedure for its implementation. In our opinion, it is necessary to harmonize and unify the forms and methods of tax control; the main types of tax audits and procedures for their conduct should be clearly defined in the national legislation; the terms of tax audits and the methods of their calculation should be unified, since each country uses its own calculation: in Russia - months, in other states - days (working or calendar); it is necessary to consider creating unified forms of decisions on the results of tax audits.

The Model Tax Code for CIS member-states, whose main purpose is to develop common approaches to regulating tax relations, could provide some assistance in addressing these issues. The more so since all of the EAEC member states are simultaneously members of the Commonwealth of Independent States. Despite the fact that Article 92 of the General Part of the Model Tax Code for CIS Member States, adopted by the Interparliamentary Assembly of CIS Member States on December 9, 2000 (Resolution No. 16-5, 2014), fully reproduces the content of Article 82 of the Tax Code of the Russian Federation regarding the forms of tax control, already Part 3 of the Model Tax Code for CIS Member States, adopted by the Interparliamentary Assembly of CIS Member States on April 19, 2019 (Resolution No. 49-11), section II "Tax Control" begins with a detailed elaboration of the Model Tax Code. Only then, Chapter 5 of this section begins to regulate in detail the procedure for tax audits. It should also be noted that the Model Tax Code for CIS member states regards tax monitoring (a form of tax control known under Russian tax law) as a mechanism for preventing tax disputes (Chapter 10 of Section IV), which, in our opinion, is more in line with the specifics of tax monitoring.

Thus, the analysis of the tax legislation of the EAEC member-states regarding the forms of tax control allows us to conclude that despite certain differences in the procedures for carrying out control measures, our countries have common approaches to the legal regulation of forms of tax control and certain conditions that may form the basis for unification and harmonization of tax legislation of the Eurasian Economic Union member-states. This will greatly contribute to the intensification of trade and economic cooperation among EAEC Member States, business activity in our countries and their sustainable economic growth. 


\section{References}

A review of tax systems of the Eurasian Economic Union member states. (2019). N.T. Mambetaliev (Ed.). Moscow. Official website of the Eurasian Economic Commission. Available from: http://www.eurasiancommission.org/ru/Documents/О6зор\%20налоговых\%20систем\%20Издание\%20ЕЭК\%202019.pdf

Resolution No. 49-11 of the Interparliamentary Assembly of the CIS Member States "On the third part of "Tax Administration" of the Model Tax Code for the CIS Member States". (2014). Unified Register of Legal Acts and Other CIS Documents. Available from: http://cis.minsk.by/

The Tax Code of the Kyrgyz Republic No 230. (2019c). Information system "Paragraph". Available from: https://online.zakon.kz/m/document?doc id=30355506

The Tax Code of the Republic of Armenia NR-165. (2016). Official website of the National Assembly of the Republic of Armenia [electronic resource]. Available from: http://www.parliament.am/law docs5/011116HO165 rus.pdf

The Tax Code of the Republic of Belarus. (2018). The Law of the Republic of Belarus No 159-3). National Legal Internet Portal of the Republic of Belarus. Available from: http://www.nalog.gov.by/uploads/documents/NK ot 2018-12-30 N 159-z.pdf

The Tax Code of the Republic of Kazakhstan "On Taxes and Other Obligatory Payments to the Budget. (2019b). Tax Code No 120-VI. The Reference Control Bank of the NBRK in electronic form. Available from: https://zan.gov.kz/client/\#!/doc/117004/rus

The Tax Code of the Russian Federation (Part I) No 146-FZ (2019a). Reference legal system "Garant". Available from: http://ivo.garant.ru/\#/document/10900200/paragraph/1:2/

Treaty on the Eurasian Economic Union (2014). Official Internet portal of legal information. Available from: http://www.pravo.gov.ru/

\section{Citation:}

Ignatovskaya, I., Grinchinko, N., Zubkova, V. (2020). Legal regulation of tax control in the Eurasian Economic Union: environmental implications. Ukrainian Journal of Ecology, 196), 118-120.

\begin{tabular}{|l|l}
\hline$(c))$ EY \\
\hline
\end{tabular} 